\title{
Empowering Women For Sustainable Development Through Active Participation In Social Enterprise's Sector In Pakistan
}

\author{
Khalid Mahmood Iraqi \\ Department of Public Administration \\ University of Karachi \\ Tehmina Faisal \\ Department of Public Administration \\ University of Karachi
}

\begin{abstract}
Women are around $51 \%$ of the total population of Pakistan, and they can do miracles through their active participation in economic activities of the country. Empowering women means accrediting half of the population for sustainable development. The aim of this paper is to examine and analyze the impact of active women participation in the social enterprise sector for their empowerment, and its subsequent consequences in creation of social value in society. For this purpose, primary data has been collected through random and snowball sampling to gain insight into female practitioner's perspective. The paper highlights women empowerment as a multi-dimensional phenomenon based on four dimensions: psychological, social, economic and political empowerment. It prime focus on active participation in the social enterprise's sector may lead to increase in enablement of women, the data shows that majority of female entrepreneur responded that they feel psychologically empowered and have financial contribution in household expenses and in community welfare. Secondly, the paper identifies the major challenges including concern of safety and security, lack of access to financial opportunities and social acceptance of the project that restrict women entrepreneurs from progress and creation of social value. Thirdly, it intends to construct framework for recommendations to promote women social enterprises in Pakistan for sustainable development as a whole.
\end{abstract}

Keywords: Women Empowerment, Sustainable Development and Social Enterprise.

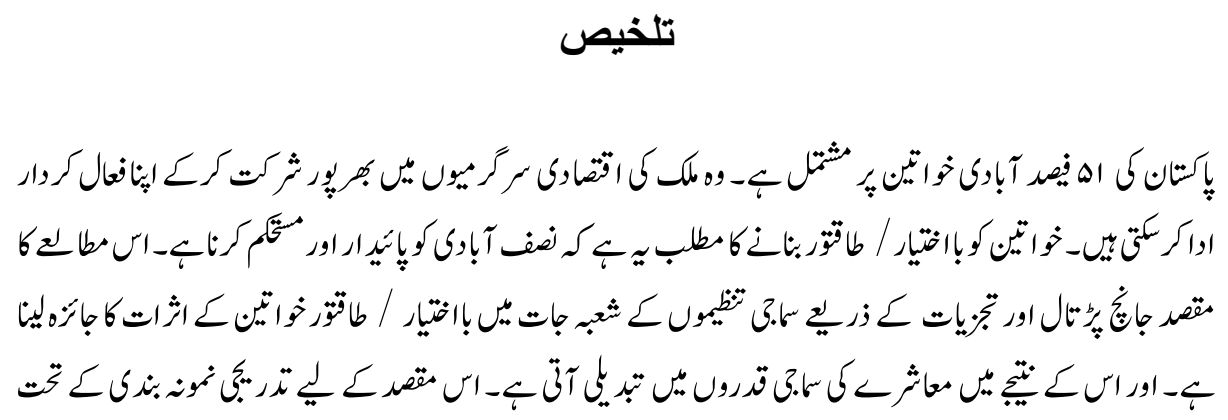




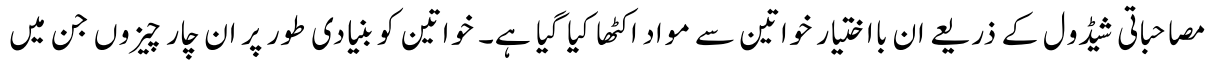

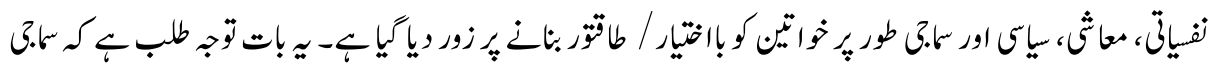

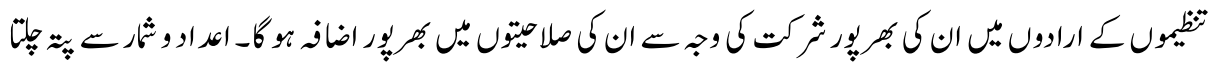

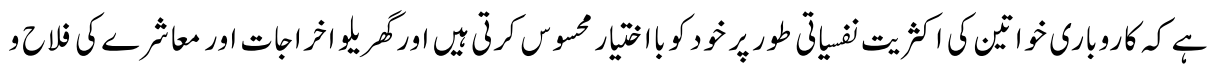

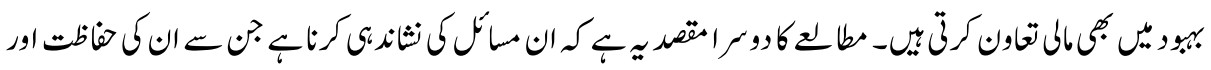

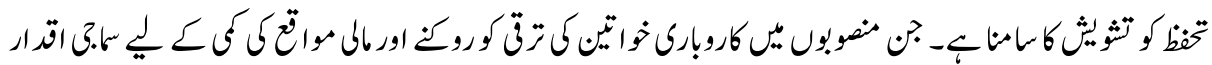

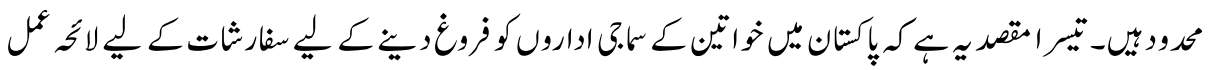

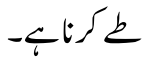

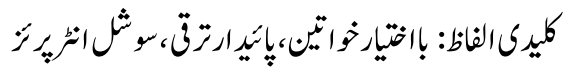

\section{Introduction}

"There is no tool for development more effective than the empowerment of women and girls," UN Secretary General Kofi Annan at the sixtieth anniversary of the Commission on the Status of Women said (Press Release, UN, 2006).

The World Bank officially identified empowerment as a major concern to reduce poverty in its World Bank Development Report 2000 - 01; the report defined empowerment as the "capacity to make effective choices"(Alsop \& Heinsohn, 2005) Consequently, 'Women empowerment' has been a serious concern for countries around the world to the point that it has been ranked third in the Millennium Development Goals (MDG) ${ }^{1}$ where member countries pledge to, "promote gender equality and the empowerment of women as effective ways to combat poverty, hunger and disease and to stimulate development that is truly sustainable"(UNFPA , 2000).

The need for empowerment and enablement of women grew as societies became more industrialized; stimulating economists and social scientists to identifying ways to fulfill the human capital deficits in social and economic progress of countries. They recognized that women are often restraint to explore their potential as significant social units and undermined their intellect and abilities to perform due to their limited exposure in the economic activities within their communities. The situation remains low in developing economies where women population is tangled in cultural and religious norms and familial responsibilities most often discouraged to perform actively in societal growth and national development. 
This research paper aims to highlight the tools of empowerment through active participation of women in social enterprise's sector for sustainable development in the country. The topic of research has been chosen due to women changing lives in last 30 years as they become more emancipated as never before (Safavian \& Haq, 2013). It is also observed that women economic participation increasing but still women are facing many problems due to existing socio-economic problems (Cheng, 2018). It is believed that women participation in economic activities could have positive impacts, which can enhance the status of women in the society and bring positive development in their personal lives and society as a whole. As the research has prime focus on the inclusion of female into social enterprise's sector of Pakistan, so it also a point of focus that male dominancy can only be reduced through female financial stability, and for that reason women's economic liberation is necessary, which could be proven as concrete step for achieving women empowerment. It could lead to pave way in decision making of private or public spheres, which enables women to lead within their communities.

It is acknowledged that women empowerment has few major components which could be developed through entering women into social enterprise's sector; firstly, it enhances the sense of self-worth (Hunt \& Samman, 2016), a right to have control their lives (Morgan, 2014), and can influence on bringing social change (Stongol, 2016) in order to build just society. The paper also identifying the challenges faced by women entrepreneurs, as it is observed that there are many interrelated and interdependent socio-economic and political dimensions which hinders women from further development of their enterprises.

There is also one of prime objectives is to enlighten the role of female entrepreneurs and a connection between enablement of women while thriving the social values. As in previous literatures, it is highlighted that by nature women are nurturing, and they have demanded fundamental rights for all sexes on equality basis. Due to such reason, it is envisaged that women can foster patriotism, human dignity, sacrifice, democracy and can bring societal unbalanced behaviors on right path in many ways. The paper also found some similar facts related to support in social development which are evaluated in later part of data analysis and discussion.

It can be said that for overall sustainable development growth; foremost thing is that every developing and under developed country has to strengthen and should invest in their human capital without any discrimination among sexes while delivering education and facilities of primary healthcare. These timely and ultimate measures would have positive impacts on psychological, social, economic and political empowerment of women, which increases self-confidence to perform well and to evaluate their self-worth 
through the inclusion in social enterprises. And then move forward to achieve social and economic development at national level, which helps nations to bring at par with the developed economies of the world.

\section{Literature Review}

Social scientists have attempted to explain women empowerment as a social phenomenon that is developed through three interrelated dimensions (1) access to resources - such as education, vocational training, financial support and mentorship (2) agency - stimulates the confidence to make independent purposive choice (3) achievements - are the positive outcomes of purposive choices that enable women to play a significant role in their personal development and in social development agency (Kabeer, 1999). The model requires progress in all dimensions to fully implement women enablement, lacking in anyone area may cause the theoretical model to exhibit ineffective or insignificant results. Most research in this field has been conducted for the economic empowerment of women while implying that such form of agency and achievement would vastly contribute to self-development and self-confidence. However recent research signifies that women development is a relative term that exhibits varying concepts and practices in different cultures and regions around the globe. Therefore, it feasible to establish a wide pragmatic spectrum that encompasses desired behavioral responses and events that defines the scope of empowerment while also identifying the extent of liberation among women. These include (a) perceived increase in self-worth and individual dignity; (b) perceived safety of living environment (c) choice of education and career (d) right to reproductive health (e) economic status (f) bodily integrity (g) control and influence over household and public resources (Kantor, Women Empowerment Through Homebased Work: Evidence From India, 2003)(h) influence over decision making (Kantor, Women Empowerment Through Home-based Work: Evidence From India, 2003)(i) emotional health (j) notion of social acceptance etc.

\section{Dimensions of Women Empowerment}

It is evident that women liberation and empowerment is a process rather than one single event or behaviour and is spread over a wide spectrum of indicators that define women empowerment in a specific culture or situation. Therefore, we can further acknowledge that women empowerment is not just enablement to make purposive economic choices, rather it's more of a holistic development through sets of behavioural changes in four major dimensions:

(1) Psychological empowerment -degree of perceived increase in self -worth and self-respect that further enhances the ability of women to achieve desired 
outcomes and bring sustainable development through positive social change (Sharma, 2017).

(2) Social empowerment - refers to the extent of liberation from restrictive social norms and socially acceptable behaviours. It also includes increase in favourable individual and collective responses in social relationships (Calás, Smircich, \& Bourne, 2009). Such favourable responses would construct a positive environment for women to take advantageous decisions.

(3) Economic Empowerment - refers to enhanced access to economic opportunities to work and utilize their skills and capabilities in return for consummate financial benefits. Thus economic empowerment would lead to direct impact on national progress at all levels: (1) micro-level - significant rise in self-believe and individual achievements (2) meso level -increase in purposive and informed responses and choices for family and community (3) macro level - increase in agency in broader societal context (Huis, Hansen, Otten, \& Lensink, 2017). Economic empowerment remains the most significant dimension that facilitates in establishing the other dimensions as well(Kantor, Determinants of Women's Microenterprise Success in Ahmedabad, India: Empowerment and Economics, 2005).

(4) Political empowerment- This dimension of empowerment enables women to make meaningful choices in voicing their opinion, active participation over elected seats and influence political agenda, policy development and policy implementation as active agents of change(Luke, 1974; Cingranelli \& Richard, 2010).

\section{Women Development in Pakistan}

Despite substantial efforts women development is in a tragic state of affairs in Pakistan mainly due to the failure of governance in reducing the widened gap between policy development and policy implementation. Among 149 countries around the globe, the World Economic Forum has ranked Pakistan as the second worst country in terms of gender equality and lowest in South Asian Region, in Global Gender Gap Index $2018^{2}$ (Ahmed, 2018). According to the United Nations Development Program - Pakistan, the country has a Gender Inequality Index $(\mathrm{GII})^{3}$ value of 0.541 . It roughly loses $3.73 \%$ of the HDI value due to gender inequality indicating alarming low values for all three dimensions of human development: (1) education - expected years of schooling for women is 7.8 years against 9.4 years for men (2) health - access to health facilities is lower as compared to men (3) employment - represent $24.9 \%$ of workforce as compared to $82.7 \%$ for men (UNDP-Pakistan, 2018). While the Women, Peace and Security Index $2017^{4}$ ranks Pakistan as 4th amongst countries that are deemed worst for women in terms 
of their peace, security, inclusion, and justice (ExpressTribune, 2017).This projects an alarming situation for almost half the population in the country. In their traditional roles as efficient contributors to management of domestic affairs, women frequently exhibit hard work, commitment, skill, innovation and intelligence; restraining them from progressing as a human being and denying them equal and fair share of opportunities, indicates towards waste of human capital that amplifies into a huge loss to economic development. A recent research by the International Monetary Fund (IMF) ${ }^{5}$ calculates that Pakistan can improve its GDP by a phenomenal 30\% if it enables and empowers its female population to explore avenues for education, engagement and employment (IMF, 2018).

\section{Enabling and Empowering Women Through Social Entrepreneurship}

Social entrepreneurship is a budding concept in Pakistan (Asif et al., 2018), it is conceptualized as a business solution to address a social dilemma. The phenomenon is often referred for sustainable development to attend to social needs especially at the community level.

The notion of women's empowerment is based on a double facet prognosis of (i) social justice and (ii) women's empowerment as means to ends; therefore it is advocated that empowered women perform as 'active subjects and agents of social change '(Chaudhry, Chani, \& Pervaiz, 2012). Social entrepreneurship is a unique platform that may engage women in community development and social welfare while benefiting them with financial returns (Opati, 2014). Female social entrepreneurship has gained much attention in recent years owing to its positive outcomes of women enablement, financial stability and active women participation in community welfare thus creating a significant impact on their self-respect and personal development (Farhan, 2017) (Coughlin \& Thomas, 2002).

A comprehensive report released by British Council in 2017 regarding prospects of women empowerment through social entrepreneurship highlights that in Pakistan 20\% of social enterprise are led by females while $37 \%$ of workforce comprises of women. The report reveals that $62 \%$ females associated with SEs reported an increase in selfworth, $71 \%$ identified increase in confidence, $43 \%$ admitted to receiving respect in families while 58\% admitted that their respect increase from other members of the community (British Council , 2017). Women in Pakistan face immense social and religious pressure in their struggle to achieve equality in rights and access to opportunities including access to education, mobility constraints, gender discrimination, gender labels, limitations in access to financial resources and a substantial fear of safety 
and security; these serve as huge barriers to women development (Syed \& Ozbilgin, 2015). The government of Pakistan has taken initiatives in terms of policies for women development and protection; however due to lack of sincere efforts for policy implementation by civil forces and weak legal frameworks, women mostly remains deprived of their right to justice and progress. Through education, vocational training and income-generating opportunities women may overcome socio-cultural and economic constraints and are enabled to exercise control over human, material and intellectual resources (World Bank, 2012). Research suggests that women social enterprise enables women to contribute to community development; such form of work is seen as respectful and socially acceptable because of its beneficial social outcomes for the community and is also approved by local religious influencers due to its charitable nature. "Promoting women's engagement and leadership in the social enterprise sector could help shift the perception of women as beneficiaries of assistance, to promote them as agents of positive change" (Akhtar, 2017).

Social enterprise engages women to promote feasible, inventive business solutions to social issues such as education, health, job opportunities, civic engagement, advocacy, environment etc to stimulate positive social change (Branzei, 2012) (Lekoko, 2015). Our study intends to explore the potential in the question 'whether social entrepreneurship can play a significant role in empowering women in Pakistan.'

\section{Research Objectives}

- To comprehend the trends of women empowerment in Pakistan

- To enlighten the association between social entrepreneurship, enablement of women and social value

- To identify the challenges that restrict women in participating in the social enterprise sector in Pakistan

- To recommend ways to promote social entrepreneurship among women and efficiently increase their participation

\section{Methodology}

The study constructs that women who are engaged in social business would experience four dimensions of empowerment: (1) psychological empowerment - personal development and increase in confidence to make independent choices (2) social empowerment - confidence to break restrictive social norms and increase in positive responses from family and community (3) economic empowerment - improvement in living conditions (4) political empowerment - advocacy on various social issues and 
active participation in community / national politics. This substantial change in behaviour and attitude of societal members around women thus creating positive social value at individual, community and societal levels. The research also identifies significant challenges as perceived by women social entrepreneurs that restricts efficiency and effectiveness in their progress.

The data for research analysis has been extracted through two methodologies 'questionnaire survey' and 'review of existing literature'. For the purpose of this research, 20 women social enterprise located in various areas of Pakistan (see table 1) have been selected through random and snowball sampling to gain insight into female practitioner's perspective on (1) extent of empowerment and (2) challenges confronted as social entrepreneurship as a promising sector for women empowerment and development.

\section{Data Analysis and Discussion}

Data collected from survey (see Table 1) revealed that 100\% female social entrepreneurs have experienced an increase in self-worth and self-confidence, $60 \%$ females have admitted to increased autonomy in taking decisions in personal and professional life, and $80 \%$ of respondents have informed that it increases their financial independence. Therefore, reflecting a significant increase in the indicators for psychological empowerment.

Subsequently, after establishment of their own enterprise, $50 \%$ of women social entrepreneurs admitted that the inclusion increased in decision making matters related to family and community issues, and $60 \%$ experienced and increase in positive and inclusive behaviours/responses from family and community in social gatherings. Thus, reflecting a significant increase in the indicators for social empowerment. It further probed that social enterprise are strongly advocating women liberation, empowerment and freedom of choice, and however women enterprises are often faced with criticism from society due to prevailed patriarchal norms in the Pakistani society. However, female social enterprises with welfare objectives that do not challenge the patriarchal norms, through socially accepted and encouraged.

Furthermore, $50 \%$ female oriented social enterprises admitted that their autonomy increased while taking financial decisions in personal and professional life, while $100 \%$ females admitted that they are contributing in financial matters of household expenses, and $100 \%$ females revealed that they contribute financially towards various forms of welfare and charity work in their communities. This clearly exhibits that economic empowerment of women would have direct and significant impacts on improving the living standards and for community development; however, even with this noticeable impact $50 \%$ of females are dependent on their male family members for financial decision even on their self-earned income from their enterprises. 
About $20 \%$ female entrepreneurs response towards political situation has been increasing, while $30 \%$ females also identified significant change in their voting behaviour after establishment of their own SE, and 20\% women experienced increased advocacy towards social and governance issues over established local, national or international platforms. Most women notified a comparatively lower response towards the indicators of political empowerment. Further investigation has found that here are few females who avoid political engagement of any form due to several reasons (in order of priority) -(1) social acceptance (2) lack of trust in government (3) concerns for safety and security (4) do not have an interest in national politics (5) feel that their opinions do not matter.

Table: 1

Perceived change in behavioural responses after establishment of own social enterprise

\begin{tabular}{|l|l|c|}
\hline $\begin{array}{c}\text { Dimension of Women } \\
\text { Empowerment }\end{array}$ & $\begin{array}{c}\text { Perceived Change in Behavioural Responses } \\
\text { after Establishment of Own Social Enterprise }\end{array}$ & $\begin{array}{c}\text { Response } \\
\text { Rate* }\end{array}$ \\
\hline Psychological & Increase in self-worth and self confidence & $\mathbf{1 0 0 \%}$ \\
\hline & $\begin{array}{l}\text { increased autonomy in taking decisions in } \\
\text { personal and professional life }\end{array}$ & $\mathbf{6 0 \%}$ \\
\hline Social & Increase in financial independence & $\mathbf{8 0 \%}$ \\
\hline & $\begin{array}{l}\text { Increased inclusion while decision making for } \\
\text { family and community issues }\end{array}$ & $\mathbf{5 0 \%}$ \\
\hline Economic & $\begin{array}{l}\text { increase in positive and inclusive } \\
\text { behaviours/responses from family and } \\
\text { community in social gatherings }\end{array}$ & $\mathbf{6 0 \%}$ \\
\hline & $\begin{array}{l}\text { increased autonomy in taking financial decisions } \\
\text { in personal and professional life }\end{array}$ & $\mathbf{5 0 \%}$ \\
\hline & $\begin{array}{l}\text { Financial contribution towards any household } \\
\text { expenses }\end{array}$ & $\mathbf{1 0 0 \%}$ \\
\hline Political & $\begin{array}{l}\text { Financial contribution towards any form of } \\
\text { community welfare work }\end{array}$ & $\mathbf{1 0 0 \%}$ \\
\hline & $\begin{array}{l}\text { increased response towards political situation in } \\
\text { the country }\end{array}$ & $\mathbf{2 0 \%}$ \\
\hline Significant change in voting behavior & $\mathbf{3 0 \%}$ \\
\hline & $\begin{array}{l}\text { Increased advocacy towards social and } \\
\text { governance issues over established local, } \\
\text { national or international platforms }\end{array}$ & $\mathbf{2 0 \%}$ \\
\hline
\end{tabular}

*Response rate in the highly significant and significant categories of the survey questionnaire. 
The above discussion clearly reflect that social enterprise's sector is empowering women in psychological and economic perspectives; however women still feel lesser empowered in social and political perspective.

Women have been facing several barriers that restrict them from enablement and empowerment. While conducting this research women SEs identified the challenges that confront them on a regular basis and negatively impacted the sustainability of their social venture included:

- Lack of access to financial resources: $70 \%$ identified access to financial resource as a significant challenge. Women are often not able to explore financial avenues due to their limited education, gender stereotypes that women are unable to make profitable financial decisions and restrictive loan policies from banks and other financial institutions.

- Gender discrimination: surprisingly only $20 \%$ females identified gender discrimination at workplace as a challenge. On further investigation, it was revealed that most social enterprises founded by females are deliberately constructed for comprising only for all-female organizational structure with minimum intervention and participation from males. Therefore, gender discrimination is hardly noticeable in such social enterprises.

- Gender stereotyping: $70 \%$ females experienced gender stereotyping as a challenge on daily basis. They are often considered lesser capable of making reasonable choices and profitable decisions, expected to leave work after marriage and children, unable to seriously passionately commit to have long term business ventures.

- Restrictive Mobility: While females are working hard to establish their own social enterprise, they are often restricted to domestic or international travelling independently. $50 \%$ females identified restrictive mobility as a challenge to their progress, although they admitted that they might be allowed to travel, for business purposes, to other cities/ countries if accompanied by a family member.

- Social acceptance of the project: Social acceptance of working women, no more remains a challenge in Pakistan from industry to agriculture women are contributing in their limited capacities. However, $70 \%$ women social entrepreneurs are still confronted with the problem of social acceptance, it was identified by the respondents that it was mainly due to their commitment to women liberation and enablement or involvement in support of other programs such as transgender rights, female reproductive rights or increasing mental health issues.

- Concerns for safety and security: safety and security remained the highest challenge for females and therefore $100 \%$ of them accepted that they experienced 
concern over their safety and security especially after the alarming increase in crime against women such as acid attacks, rape, domestic abuse and sexual harassment at workplace etc.

- Restrictive access to education and training opportunities for women entrepreneurs: $60 \%$ females admitted to have limited or no access to education and training opportunities for improving their ventures. This challenge becomes increasingly apparent when the social enterprise has successfully completed the initial stage of implementation and progresses to the level of sustainable development. For sustainable development, the organization requires capacity building in terms of human, material, financial and technological resources while they also experience the need for mentorship, training and education specifically in management of these resources effectively (OECD, 2001) (Pandey \& Indrakanti, 2017).

Table: 2

Significant challenges identified by women social entrepreneurs

\begin{tabular}{|l|c|}
\hline significant challenges identified by women social entrepreneurs & $\begin{array}{c}\text { Response } \\
\text { Rate* }\end{array}$ \\
\hline lack of access to financial opportunities & $\mathbf{7 0 \%}$ \\
\hline Gender discrimination at workplace & $\mathbf{2 0 \%}$ \\
\hline Gender stereotypes in society & $\mathbf{7 0 \%}$ \\
\hline Restrictive mobility & $\mathbf{5 0 \%}$ \\
\hline social acceptance of the project & $\mathbf{7 0 \%}$ \\
\hline concerns for safety and security & $\mathbf{1 0 0 \%}$ \\
\hline $\begin{array}{l}\text { restrictive access to education and training opportunities for } \\
\text { women entrepreneurs }\end{array}$ & $\mathbf{6 0 \%}$ \\
\hline
\end{tabular}

* Response rate in highly significant and significant categories of the survey questionnaire

\section{Conclusions}

The data has reflected a positive significant impact of social entrepreneurship in empowering and enabling women. From the in-depth discussion on women social entrepreneurs' responses on various dimensions in the earlier section, it is safe to conclude that social entrepreneurship can be utilized to enable female population in Pakistan. The data reflects social enterprise's sector is contributing more to the psychological and social empowerment of females as compared to their social and political empowerment. Women also identified various challenges that significantly affected the sustainable development of their projects the most prominent being concern for safety and security, lack of access to financial resources, lack of access to education 
and training for sustainable development of their venture, restrictive mobility and gender stereotypes.

It is evident that empowering women through active participation in the social enterprise sector can be an immense contribution in managing sustainable development.

\section{Recommendations}

Social enterprises sector can effectively contribute to women empowerment and development in Pakistan; however, it is crucial that women are encouraged to explore business solutions to social issues and provided with a conducive environment to implement social ventures for sustainable development.

1. The Ministry of Women Development may be directed to take a keen interest in supporting women entrepreneurs through devising a legal and social policy framework. Such a framework would protect women owned SEs and contribute towards sustainable development.

2. Community influencers such as social media influencers and religious community leaders can also be deliberately mobilized by the government to increase awareness and encourage females towards the social enterprise's sector.

3. It is evident that the financial dynamics of the social enterprises' is a serious concern without which it becomes challenge for women social entrepreneurs. There are several ways through which the financial opportunities can be enhanced for these budding entrepreneurs including angel investment and crowd funding, cross-sector public private partnership to pool funds for facilitation of women owned SEs, increasing in number of micro-financing institutions, government grants, private funding and venture philanthropy.

4. It is also critical that young females are made familiar with the concept of social entrepreneurship and social innovation from early years of education and training so that they are more aware of its positive impact on psychological empowerment and community development.

\section{End Notes}

1. The United Nations Millennium Development Goals are eight goals that all $191 \mathrm{UN}$ member states have agreed to try to achieve by the year 2015. For further description visit https://www.un.org/millenniumgoals/ last accessed on June 10, 2019

2. The Global Gender Gap Index 2018 was developed based on 4 criteria economy, education, health and politics

3. For further details on GII visit http://hdr.undp.org/en/content/gender-inequalityindex-gii; last accessed on June 8, 2019 
4. The Women Peace and Security Index is presented by Georgetown Institute for Women, Peace and Security. For details visit https:/giwps.georgetown.edu/country/pakistan/ ; last accessed on June 8, 2019

5. Report available athttps://www.imf.org/ /.../pp053118pursuing-womenseconomic-empowerment.ashx ; Last accessed on June 8, 2019

\section{References}

Ahmed, A. (2018, December 19). Pakistan Among Worst Performers on Gender Inequality. Retrieved from www.dawn.com: https://www.dawn.com/news/1452284

Akhtar, S. (2017). Activist to Entrepreneur. Islamabad: British Council.

Alsop, R. \& Heinsohn, N. (2005). Measuring Empowerment in Practice Structuring Analysis and Framing Indicators . USA: World Bank .

Asif, Mubeen, Asghar, Faisal, Younis, Amna, \& Mahmood, Amir (2018). The Role of Social Entrepreneurship in Pakistan and Its Impact on Economy, International Journal of Business, Economics and Management, vol.5:5, p.117.

Branzei, O. (2012). Social Change Agency Under Adversity: How Relational Processes (re)produce Hope in Hopeless Settings. In K. Golden-Biddle, \& J. Dutton, Using a Positive Lens to Explore Social Change in Organizations: Building a Theoretical and Research Foundation (pp. 21-47). London : Routledge.

British Council . (2017). Activist to Entrepreneur: The Role of Social Enterprise in Supporting Women's Empowerment in Pakistan . Islamabad: British Council .

Calás, M., Smircich, L., \& Bourne, K. (2009). Extending the boundaries: Reframing'Entrepreneurship as Social Change' Through Feminist Perspectives. Academy of Management Review , 552-569.

Chaudhry, A. R., Chani, M. I., \& Pervaiz, Z. (2012). An Analysis of Different Approaches to Women Empowerment: A case study of Pakistan . World Applied Sciences Journal , 971-980.

Cingranelli, D. L., \& Richard, D. L. (2010). CIRI Human Rights Data Project. Human Rights Quarterly, 401-424. 
Cheng, Marguerota (2018, October 31). 8 Major Challenges Women Faces in Business, Forbes. Retrieve from: https://www.forbes.com/sites/margueritacheng/2018/10/ 31/8-major-challenges-women-face-in-business/\#242066ab6461 on July 2, 2019.

Coughlin, Jeanne, H. \& Thomas, Andrew (2002). The Rise of Women Entrepreneurs: People, Process and Global Trends, Quorum Books, London, p. 89.

Desai, M. (2010). Hope in Hard Times: Women Empowerment and Human Development. Washington: United Nations Development Program .

ExpressTribune. (2017, November 29). Pakistan Fourth Worse Country for Women. Retrieved from www.tribune.com.pk: https://tribune.com.pk/story/1571978/1pakistan-fourth-worst-country-women-study/

Farhan, Fiza (2017, November 4). Inclusive Growth Through Social Entrepreneurship, The Express Tribune. Retrieve from: https://tribune.com.pk/story/1549205/6inclusive-growth-social-entrepreneurship/ on July 2, 2019.

Huis, M. A., Hansen, N., Otten, S., \& Lensink, R. (2017). A Three-Dimensional Model of Women's Empowerment: Implications in the Field of Microfinance and Future Directions. Frontiers in Psychology, 247- 264.

Hunt, Abigail \& Samman Emma (2016). Women's Economic Empowerment: Navigation Enablers and Constraints, Overseas Development Institute, London, p. 9.

IMF . (2018). Pursuing Women's Economic Development. Washington, USA: International Monetary Fund.

Kabeer, N. (1999). Resources, Agency and Achievement: Reflections on the Measurement of Women Empowerment. Development and Change, 435-464.

Kantor, P. (2005). Determinants of Women's Microenterprise Success in Ahmedabad, India: Empowerment and Economics. Feminist Economics , 63-83.

Kantor, P. (2003). Women Empowerment Through Home-based Work: Evidence From India. Development , 425-445.

Luke, S. (1974). Power: A Radical View. London : Macmillan Press.

Lekoko, Rebecca, N. (2015). Cases on Grassroots Campaigns for Community Empowerment and Social Change, IGI Global, USA, p.44. 
Morgan, Brittney (2014, October 24). Most US Women Entrepreneurs Motivated by Work-Life Balance, Business News Daily. Retrieve from: https://www.businessnewsdaily.com/7341-women-entrepreneurs-motivation.html on July 2, 2019.

OECD. (2011). Women's Economic Empowerment. Paris: OECD-DAC GENDERNET.

OECD (2001). International Science and Technology Co-Operation towards Sustainable Development, OECD Publication, France, p. 68.

Opati, Morris, S. (2014). Influence of Social Entrepreneurship Strategies on Community Empowerment among Faith-Based Organizations in Kajiado County, Kenya, p. 4.

Pandey, Umesh \& Indrakanti, Verlaxmi (2018). Open and Distance Learning Initiatives for Sustainable Development, IGI Global, USA, p.149.

Press Release, UN. (2006, November 10). Press Release. Retrieved from www.un.org: https://www.un.org/press/en/2006/wom1586.doc.htm

Sharma, S. (2017). The Dynamics of Women's Empowerment: A Critical Appraisal. Social Change, 387- 405.

Safavian, Mehnaz \& Haq, Aban (2013). Are Pakistan's Women Entrepreneurs Being Served by the Microfinance Sector, The World Bank Publication, Washington DC, p. 7.

Syed, Jawad \& Ozbilgin, Mustafa (2015). Managing Diversity and Inclusion: An International Perspective, Sage, New Delhi, p.128.

Stongol, Gori (2016, February 3). Women Entrepreneurs Fuel Social Changes and Economic Growth, Forbes. Retrieve from https:/www.forbes.com/sites/ geristengel/2016/02/03/women-entrepreneurs-fuel-social-change-and-economicgrowth/\#22150e2b2c59 on July 2, 2019.

UNDP-Pakistan. (2018, September 16). Human Development in Pakistan. Retrieved from www.pk.undp.org:

http://www.pk.undp.org/content/pakistan/en/home/blog/2018/humandevelopment-in-pakistan.html

UNFPA . (2000, Jan 12). Issue 7: Women Empowerment. Retrieved from www.unfpa.org: https://www.unfpa.org/resources/issue-7-women-empowerment 
World Bank. (2012). World Development Report - Gender Equality and Development. Washington: World Bank .

Young, K. (1993). Planning Development with Women: Making a World of Difference. London : Macmillan.

Dr. Khalid Mahmood Iraqi is Professor in the Department of Public Administration and Former Dean, Faculty of Management Sciences, University of Karachi.

Tehmina Faisal is Lecturer in the Department of Public Administration, University of Karachi. 